\title{
A smoking gun for copper enrichment in arc volcanoes?
}

\author{
TERESA UBIDE', Fidel COSTA², MARK A. KENDRICK', \\ ANDREW J. BERRY ${ }^{3}$ \\ 'School of Earth and Environmental Sciences, The University \\ of Queensland, Australia.t.ubide@uq.edu.au \\ 2Earth Observatory Singapore, Nanyang Technological \\ University, Singapore \\ ${ }^{3}$ Research School of Earth Sciences, Australian National \\ University, Australia
}

Calc-alkaline magmas above subduction zones sometimes host porphyry copper ore deposits, which supply $70 \%$ of the world's copper. As a result, there is great interest in the possible causes of copper enrichment in parental arc magmas, and copper-sulphide precipitation mechanisms, which may involve gas fluxes related to magmatic rather than hydrothermal processes [1,2].

Here we combine passive degassing $\mathrm{SO}_{2}$ fluxes with records of $\mathrm{Cu}$ and $\mathrm{S}$ enrichment in associated eruptions. We compare open-vent volcanoes in the southwest Pacific, including Mount Mayon in the Philippines and Mount Merapi in Indonesia, and apply high-resolution crystal-scale elemental mapping to explore copper sulphide precipitation in the subvolcanic environment.

Melts preserved in channels in sieve-textured plagioclase phenocrysts erupted from Mount Mayon in 2006-2009, when there was an elevated $\mathrm{SO}_{2}$ degassing flux, are extensively crystallised and contain clinopyroxene and magnetite together with droplets of copper sulphide (digenite). The bulk composition of the melt inclusions (including crystals) is that of a relatively evolved andesite-dacite, similar to typical arc lavas but with exceptional $\mathrm{Cu}$ enrichment. The residual melt is rhyolitic and enriched in halogens, with up to $1 \mathrm{wt} . \% \mathrm{Cl}(\sim 3 \mathrm{x}$ typical arc magma values). Similar melt inclusions in plagioclases from the large 2000 Mount Mayon eruption, at the onset of passive degassing, and from Mount Merapi, which has $\mathrm{SO}_{2}$-degassing fluxes one order of magnitude lower than Mayon, lack equivalent copper-enrichment.

These observations suggest that gaseous $\mathrm{SO}_{2}$ fluxes may exert a critical control on magma copper endowment. Gaseous $\mathrm{SO}_{2}$ fluxes might cause early sulphide saturation preventing copper enrichment of evolved magmas. Alternatively, flushing of shallow plagioclase mushes with sulphur-rich vapours as well as $\mathrm{Cu}$-bearing magmatic brines might be a critical step in the enrichment of arc magmas necessary for the production of large and super-large ore deposits.

[1] Blundy et al., 2015. Nature Geosci. [2] Henley et al., 2015. Nature Geosci. 